\title{
The Effectiveness of Organic Waste Treatment Training to the Knowledge, Attitude and Skill Enhancement of Family Welfare Programme Group in North Purwokerto Health Center Working Area
}

\section{Muharnis Supriyani Putri ${ }^{1}$ and Dewi Susanna ${ }^{2}$}

${ }^{1}$ Postgraduate Student Faculty of Public Health, Universitas Indonesia, Depok, Indonesia

${ }^{2}$ Faculty of Public Health, Universitas Indonesia, Depok, Indonesia

\section{Abstract}

Garbage is a daily waste of human activity or a natural process in a solid or semi-solid form. Composting is a decomposition process of organic waste either in aerobic or anaerobic. Many people do not understand how to recycle organic waste into compost. This research was aimed to know the effectiveness of biological waste treatment training

Corresponding Author: Muharnis Supriyani Putri muharnis93@gmail.com

Received: 26 December 2018 Accepted: 23 February 2019 Published: 7 March 2019

Publishing services provided by Knowledge E

(c) Muharnis Supriyani Putri and Dewi Susanna. This article is distributed under the terms of the Creative Commons

Attribution License, which permits unrestricted use and redistribution provided that the original author and source are credited.

Selection and Peer-review under the responsibility of the 2 nd International Meeting of Public Health 2016 Conference Committee. to the knowledge, attitude, and skill enhancement of Family Welfare Programme (FWP) or 'Pendidikan Kesejahteraan Keluarga (PKK) group in North Purwokerto health center working area. This research used Quasi-experimental with non-randomized pre-test and post-test with control group research design. Wilcoxon's test result showed that there were differences between knowledge, attitude, and skill before and after the training of group sample with the value of $p=0.014$ for learning, 0.037 for the position, and 0.001 for ability. So, the test result of Wilcoxon group did not show the differences of the knowledge, attitude, and skill before (pre-test) and after (post-test) with the value of $\mathrm{p} 1.000$ for learning, 0.863 for the position, and 0.527 for talent. Mann-Whitney's test result did not show differences in the knowledge, attitude, and skill, in both group sample and group comparison with the value of $\mathrm{p} 0.072$ for learning, 0.457 for the position, and 0.457 for talent. Mann-Whitney's test result did not show differences in the knowledge, attitude, but there were differences between genius in both group sample and group comparison with the value of $\mathrm{p} 0.804$ for education, 0.289 for the position, and 0.00 for ability. After this training hopefully, the PKK group can disseminate organic waste treatment skill to the other communities.

Keywords: Training; organic waste; compost, PKK

\section{Introduction}

Garbage is an item that has been categorized unused item, but it still can be used and managed with the right procedure. Trash is one of the complex problems that is faced by 
developing country. In 2014, volume of solid waste in Indonesia was estimated to reach 13.000 tons/day (Kementerian Pekerjaan Umum, 2014).

Substantial waste problems in Banyumas district have increased because of increasing human activities. In 2013, the volume of waste solids in Banyumas reached 1,650,234 $\mathrm{m} 3$ whereas the amount of waste transported solid was just $165.857 \mathrm{~m}^{3}$ (13.35\%). Meanwhile, according to SNI 3242/2008, waste substantial standard transported from the dumpster to the landfill is more than 63\% (Badan Lingkungan Hidup Banyumas, 2009).

The grinding village is one of the communities at North Purwokerto sub-district in Banyumas district with high population density. In the village profile, it records that 6,594 whole populations are living in an area of 70.9 hectares - the volume of waste solid produced by Grendeng village's community is average of $6 \mathrm{~m}^{3}$ /day (Hapsari, 2014).

Family Welfare Programme (FWP) or PKK group has a vital role because the FWP group is one of the groups on society that has a goal to increase public welfare (Dwiyanto, 2011). Based on research conducted by Dwiyanto (2011), FWP group's skill of organic waste treatment can be upgraded by processing organic waste into compost. Training is one of the processes that can change human ability, individual and community behavior or organization of climate change. The advantages of the training are to develop skills so that work can be completed more quickly and more effectively. The background above encouraged researcher to know "Organic Waste Training Effectiveness in Improving Knowledge, Attitudes, and Skill on the FWP in North Purwokerto Health Center Working Area."

\section{Methods}

The research type used in this research was Quasi-experimental with non-randomized pre-test and post-test with control group design, subjects were divided into two groups including treatment group and a comparison group that could be measured before and after the procedure.

Sampling technique used Purposive Sampling with inclusion and exclusion criteria.

\subsection{Inclusion criteria}

She must be the head of the FWP group from neighborhood, hamlet, or village level. 


\subsection{Exclusion criteria}

She did not follow training from start to finish, she did not attend practice, and she was not willing to become respondents

The research sample of group treatment that fitted with the inclusion and exclusion criteria was 16 heads of FWP group from Grendeng village. As a comparison group, the researchers took 16 heads of FWP group from the Sumampir village in North Purwokerto district. The treatment group gave the training on organic waste management, and the comparison group was not. The researcher measured the knowledge, attitude, and skill by comparing the result of the pre-test and post-test between the treatment group and the comparison group.

\section{Results}

\subsection{Univariate analysis}

\subsubsection{Respondent characteristic}

Members of the treatment group consisted of $43-50$ age group (50\%) whereas most members of the comparison group composed of 35-42 age group (42.20\%). Members of treatment and the comparison group were high school graduates $(56.2 \%$ for the treatment group and $75 \%$ for the comparison group). Members of medicine and the comparison group were housewives $(100 \%$ for the treatment group and $87.5 \%$ for the comparison group).

\subsubsection{Overview respondents knowledge about organic waste}

Based on the results of data analysis, there was a change in respondents' knowledge in the treatment group. The average score of expertise in the treatment group pre-test was 14.81 and during the post-test, it increased to 16.25 , while the average rating of knowledge in the comparison group showed that in the pre-test was 16.18 and during the post-test, it was 16.18 .

\subsubsection{Overview respondents attitude about organic waste}

Based on the results of data analysis, there were changes in the attitude of the respondents in the experimental and in the comparison group, the average score of view in the treatment group showed, that in pre-test was 35.5 and in post-test increased to 37.5 
while the average rating of the attitude of the comparison group showed, that in pre-test was 37.81 and during the post-test was 37.31 .

\subsubsection{Overview respondents skill about organic waste}

Based on the results of data analysis, there were changes in the skill of respondents in the experimental and in the comparison group, the average score of talent in the treatment group pre-test was 5.31, and in post-test increased to 8.56 while the average rating of skills in group comparative pre-test time was 5.93, and in post-test, it was 6.06.

\subsection{Bivariate analysis}

The bivariate analysis was conducted to know the difference between before and after treatment both in the treatment and the comparison group.

\section{Discussion}

The results showed the initial hypothesis showing the same initial conditions could be seen from the results of statistical tests and the distribution of responses. The results of statistical tests of knowledge, attitudes, and skills regarding the processing of organic waste showed no significant differences in knowledge, attitudes, and skills before between the treatment and the comparison group (Arikunto, 2008). Survey respondents can be said as homogeneous if among its members have the same characteristics or general conditions. In this research, knowledge before respondent treatment group and the comparison group had similar characteristics that had most of the educated middle (high school graduation or equivalent) and mostly work as a housewife. In line with the opinion of Arikunto (2008) who argued that one of the requirements was to try an experimental study in two groups of respondents in the same conditions, it showed that exposure of the results may be the result of the presence or absence of treatment (Hasibuan, 2005).

The results of statistical tests of knowledge, attitudes, and skills concerning the processing of organic waste showed that there were differences in culture, beliefs, and abilities between before and after training in the treatment group (Notoatmodjo, 2005). Several factors influenced a person's knowledge such as education, information, social and culture, environment, experience, and age. Information is one of the factors that affect a person's intelligence. Information gained from both formal and informal education can influence short-term to produce a change or an increase in knowledge. Also, 
TABLE 1: The Results of Statistic Analysis.

Explanation
Knowledge of different test results before in
the comparison and the treatment group
Different test results before the attitude of
control and the treatment group
Results of different test skills test before the
comparison and the treatment group
The results of different test knowledge before
(pre-test) and after (post-test) in the treatment
group
Before the results of a varying test of attitudes
(Pre-test) and after (Post-test) in treatment
Group
Before the results of a different analysis of
skills (Pre-test) and after (Post-test) in the
treatment group
Prior knowledge of different test results
(pre-test) and after (Post-test) in comparison
group
Before the results of a different test of
attitudes (Pre-test) and after (Post-test) in
comparison group
Before the results of a different test of skills
(Pre-test) and after (Post-test) in comparison
group
Different knowledge in test results after in
comparison and treatment group
Different attitudes in test results after
comparison group and treatment group
Different skills test results after comparison
group and treatment group
(Pot

\begin{tabular}{|c|}
\hline $\begin{array}{c}\text { Analysis } \\
\text { statistic }\end{array}$ \\
Mann-Whitney \\
Mann-Whitney \\
Mann-Whitney \\
\hline Wilcoxon \\
\hline Wilcoxon \\
\hline Wilcoxon \\
\hline Wilcoxon \\
\hline Wilcoxon \\
\hline Walcoxon \\
\hline Mann-Whitney
\end{tabular}

\begin{tabular}{|c|c|c|}
\hline p-value & $\alpha$ & Result \\
\hline 0.072 & 0.05 & No difference \\
\hline 0.457 & 0.05 & No difference \\
\hline 0.349 & 0.05 & No difference \\
\hline 0.014 & 0.05 & $\begin{array}{l}\text { There was a } \\
\text { difference }\end{array}$ \\
\hline 0.037 & 0.05 & $\begin{array}{l}\text { There was a } \\
\text { difference }\end{array}$ \\
\hline 0.001 & 0.05 & $\begin{array}{l}\text { There was a } \\
\text { difference }\end{array}$ \\
\hline 1.000 & 0.05 & No difference \\
\hline 0.863 & 0.05 & No difference \\
\hline 0.527 & 0.05 & No difference \\
\hline 0.804 & 0.05 & No difference \\
\hline 0.289 & 0.05 & No difference \\
\hline 0.000 & 0.05 & $\begin{array}{l}\text { There was a } \\
\text { difference }\end{array}$ \\
\hline
\end{tabular}

the right knowledge and understanding can affect the perception of something that may affect the attitudes of individuals, as well as making it easier to accept or adopt positive behaviors.

The results of statistical test of knowledge about the processing of organic waste showed no differences in culture, attitudes, and skills on organic waste processing between before and after the comparison group. Learning is due to the interaction between stimulus and response. This is consistent with Skinner's theory which states that if the organism is given the incentive, it will provide the primary response in the form of open and closed answers. Increased knowledge is closed because the reaction cannot be observed directly. However, in the absence of the stimulus, the increased understanding will not be achieved in determining the attitude of the whole knowledge, thoughts, beliefs, and emotions play an essential role. Excellent experience will lead individuals to be able to think and try to be able to have the right attitude towards a 
particular object - also, changes in behavior or skill were influenced by the presence of a stimulus. However, if there is no stimulus, there will be an increase in the professions (Notoatmodjo, 2005).

The results of statistical test of skills on organic waste processing showed that there were significant differences between the skills after in the treatment and the comparison group. There was a difference of skills after (post-test) between the treatment and the comparison group because the treatment groups were given a training stimulus in the form of organic waste processing. So, it resulted in different skills of composting using mini composter between the treatment and the comparison group. The demonstration is a method of training that is done by demonstration and explanation of how to do any work through the examples. Through the targeted event, the mode can see, observe, hear, may feel the demonstrated process which the process of improvement of skills can occur more quickly.

\section{Conclusions}

Results showed no differences in knowledge, attitudes, and skills between before and after training in the treatment group with $\mathrm{p}$-value of 0.014 for the experience, attitudes and 0.037 to 0.001 for skills. As the comparison group, Wilcoxon test resulted in no differences in knowledge, attitudes, and abilities before (pre-test) and after (post-test) with $p$-value 1.000 for learning, 0.863 to 0.527 for the position and skills. Results showed no differences in knowledge, attitudes, and abilities before between the treatment and the comparison group with $p$ value of 0.072 for the experience, perspectives and 0.457 to 0.349 for skills. Results showed no differences in knowledge, attitudes, but there were differences between the talent after in the treatment and the comparison group with $p$ value of 0.804 for the experience, perspectives and 0.289 to 0.00 for skills.

\section{References}

[1] Arikunto, S. 2008. Dasar-dasar Evaluasi Pendidikan. Jakarta: Bumi Aksara.

[2] Badan Lingkungan Hidup Banyumas. 2009. Penataan Ruang Kabupaten Banyumas. Retrieved March 222015 from www.penataan ruangbanyumas.com.

[3] Dwiyanto, B. M. 2011. "Model Peningkatan Partisipasi Masyarakat Penguatan Sinergi dalam Pengelolaan Sampah Perkotaan." Jurnal Ekonomi Pembangunan, 12, 239256.

[4] Hapsari, N. 2014. "Evaluasi Program Pengolahan Smpah Bersekala Keluarga di Kelurahan Tembalang." Jurnal Teknik PWK, 3, 155-166. 
[5] Hasibuan. 2005. Manajemen Sumber Daya Manusia. Edisi Revisi. Jakarta: Bumi Aksara.

[6] Kementerian Pekerjaan Umum. 2014. Produksi Sampah capai 130.000 ton/hari. Retrieved Mei 4, 2015, from http://www.indonesia.go.id/en/ministries/ministers/ ministry-of-public-work/922-lingkungan-hidup/13887-2015-produksi-sampahcapai-130000-tonhari

[7] Notoadmodjo, S. 2005. Promosi Kesehatan dan Teori Aplikasi. Jakarta: Rineka Cipta. 